\title{
Service Quality of Border Region Higher Education Libraries
}

\author{
Muhammad Nur', Marisa S.B. Seran² \\ ${ }^{1,2}$ Universitas Timor \\ E-mail: $\underline{\text { m.nurunimor@gmail.com }}$
}

\begin{abstract}
The quality of a qualified library makes the library as one of the centers of information for the general public. This study aimed to determine how well the quality of library services, to find out how high the interest in reading students at border region state university library, and to determine the effect of the quality of college library services on strengthening the reading interest of students in the Library at the University of Timor Library UPT. This study used a qualitative descriptive approach with a sample of 100 students. Data collection was carried out through observation, interview, documentation and questionnaire techniques. The data that has been collected is processed using descriptive statistical analysis techniques and inferential statistics. The results showed that the quality of library services at the University of Timor in the border area was in the quite good category with an average of 33.48. Student reading interest was in quite a good category with a mean value of 20,56 . The level of relationship or correlation between the quality of library services at the University of Timor in the border region to the interest in reading students at the University Library of Timor is in the strong category correlation with intervals of 0.60-0.799 means that the higher the quality of library services at the University of Timor in the border region, the higher the interest in reading students in the Library.
\end{abstract}

Keywords: Quality of libraries, universities, interest in reading, border areas

\section{INTRODUCTION}

It cannot be denied that the library has a very central role in building and increasing people's motivation or attractiveness in accessing knowledge. With a quality library that is qualified to make the library as one of the centers of information for the general public (Ismail \& Darwis, 2016; Nurdin, Niswaty, \& Saleh, 2015).

Libraries that used to be one of the sources of reference information that contain various collections and library materials are now popping up a lot of news media or IT-based information sources, internet technology and mobile phones that are almost owned by every individual who wants to access information quickly, so that each individual has many choices in accessing information which is where everyone freely accesses all available information sources (Ardoni, 2006; Hayati, 2014; Istiana, 2016). The challenge of libraries as a place to access information sources is also tested by adjusting the development of the current era and era (Anita Nusantari, 2009; Fitriastuti, 2009; Pratama, Sihombing, Nugraha, \& Putra, 2014). Various advantages of the library that might not be replaced ie the existing information sources can be referred to from the original sources both books and others. This becomes the existence of library must continue to be encouraged in achieving accurate and valid information. Besides that, however sophisticated technology is, the role of libraries is inevitable. Various studies also explained that many aspects can be obtained from the library itself. One of them in sociological studies is the process of interaction between people in the library certainly cannot be replaced 


\footnotetext{
146 Jurnal Administrare: Jurnal Pemikiran Ilmiah dan Pendidikan Administrasi Perkantoran Volume 6 Number 2 July- December 2019. Pages 145-152
}

by the sophistication of existing information, plus various sources of information that cannot be obtained outside the library can be obtained in the library collection. For this reason, innovation and the quality of library services must be improved continuously. Therefore, one of the important assets of a library is to improve the quality of library services such as increasing the collection of books or literature and the easy access of information for visitors or readers (Rangkuti, 2014; Saleh \& Komalasari, 2014; Widiasa, 2007). So is the case with the existence of a library in a tertiary institution. Library in a tertiary institution is a necessity in the midst of the existing academic community. Therefore of course in the midst of an academic environment, it is imperative that universities have good and representative library support facilities (Diniaty \& Fairus, 2014; Suharti, 2017; Triatma, 2016).

The University of Timor as a new state university which is geographically located in the border region of the Republic of Indonesia-RDTL has a very central role in developing border communities where the conditions of the community cannot be compared to those of other urban areas that have advanced especially the awareness and needs of their communities. which is certainly different. This is so that the quality of the Unimor library is very much expected to have a presence in fostering the civilization of border communities and is no exception for students but also for the community at large.

Unimor's UPT Library as one of the Technical Implementation Units (UPT) in the Timor University (Unimor) institution in its journey from its establishment until now is certainly not easy. The role of the Unimor UPT Library in supporting the availability of information and reference material is tested in the midst of its existence in a university the height of the border is very much needed. UPT Unimor library must answer all the needs of the campus community and the community outside the campus in general. The lecturers and students expect the Unimor UPT Library as a representative library that can be relied upon in providing the desired information and sources of reference. Moreover, it is known together students as the successor of the nation, prospective leaders who are highly expected must have endeavored so that they can access the library as an accurate source of references and a variety of good library services obtained from the library.

\section{METHOD}

The research design used is a descriptive quantitative and correlative research design that aims to find out how well the quality of library services, how high interest in and influence the quality of higher education library services on student reading interest in the UPT Library of the University of Timor. The samples in this study were 100 people. Data collection techniques namely observation, interviews, questionnaires and documentation. Data analysis uses descriptive statistical analysis and inferential statistical analysis.

\section{RESULT AND DISCUSSION}

\section{Quality of Services at the University of Timor Library's UPT}

Following are the results of the distribution of frequency categorization of the University of Timor library service quality based on five categorizations as follows: 
Table 1.

Frequency and Percentage Distribution of Service Quality at UPT Library of the University of Timor

\begin{tabular}{|c|l|c|c|}
\hline Interval & \multicolumn{1}{|c|}{ Category } & Frequency & Percentage \\
\hline $46-50$ & Very good & 0 & 0 \\
\hline $37-45$ & Well & 24 & $24 \%$ \\
\hline $28-36$ & Enough & 56 & $56 \%$ \\
\hline $19-27$ & Not good & 20 & $20 \%$ \\
\hline $10-18$ & Very less & 0 & $0 \%$ \\
\hline \multicolumn{2}{|l|}{ Amount } & $\mathbf{1 0 0}$ & $\mathbf{1 0 0 , 0 0 \%}$ \\
\hline
\end{tabular}

Source: Questionnaire analysis results

Table 1 shows that out of 100 research respondents, none of the respondents or 0 percent were in the very good category, as many as 24 respondents or 24 percent were in the good category, and in the good enough category there were 56 percent, 20 percent were in the poor category good, and the rest no respondents or 0 percent in the very poor category. This shows that the quality of library services at the University of Timor Library UPT is still in the frequency category is quite good, this fact is supported by the average score of the results of research on service quality at the Timor University Library by 56 percent where the average value is at intervals $28-36$ which is categorized as good. From these data, it can be obtained the average data (mean) of 33.48 is in the quite good category.

This is reinforced by the results of interviews with UPT Library University Timor staff who said that "many indicators indicate that the quality of libraries in UPT Libraries is not yet maximally good, such as book reference sources, articles that are still lacking in addition to the staff at the Library are very limited. Quality at the University of Timor Library UPT is still quite good in this case it can be said that the maximum level of service at the Unimor Library is not in the good category in general.

\section{Student Reading Interest in the Library}

Based on the results of the study strengthening the reading interest of students in the library at Timor University is presented in Table 2:

Tabel 2.

Frequency and Percentage Distribution of Reading Interest at UPT Library of the University of Timor

\begin{tabular}{|c|l|c|c|}
\hline Interval & \multicolumn{1}{|c|}{ Category } & Frequency & Percentage \\
\hline $26-30$ & Very good & 16 & $16 \%$ \\
\hline $21-25$ & Well & 30 & $30 \%$ \\
\hline $16-20$ & Enough & 48 & $48 \%$ \\
\hline $11-15$ & Not good & 6 & $6 \%$ \\
\hline $6-10$ & Very less & 0 & $0 \%$ \\
\hline \multicolumn{2}{|c|}{ Amount } & 100 & $100 \%$ \\
\hline
\end{tabular}

Source: Questionnaire analysis results 


\section{Jurnal Administrare: Jurnal Pemikiran Ilmiah dan Pendidikan Administrasi Perkantoran Volume 6 Number 2 July- December 2019. Pages 145-152}

Table 2 shows that of the 100 study respondents. As many as 16 respondents or as many as 16 percents are in a good category, then 30 respondents or are in a good category, as many as 48 respondents or 48 percent are in the good enough category, the category is not good there are 6 respondents or 6 percent and no respondents are in the very less. This shows that the reading interest of students in Timor University Library is dominated in the good and fairly good category supported by the average score of the results of research on student reading interest in the Library so that it can be concluded that in general students' interest in reading at the University of Timor Library UPT 48 percent in the good enough category and as many as 30 are in the good category. From these data, it can be obtained the average data (mean) of 20.56 in the quite good category.

In addition, the results of interviews with staff at the UPT Library of the University of Timor who explained that "the reading interest of students in the University Library has been classified as good but actually not yet optimal even though basically there is an increase every year, it needs a lot of things to be encouraged including the awareness of the students themselves, it is also expected lecturers and heads of study programs within the University of Timor direct or encourage students to always visit the Library as a motivation for them to read

\section{Effect of Service Quality on Student Reading Interest in the University of Timor Library's}

Based on observations and interviews with one of the parents' representatives who said that this zoning system provides a sense of comfort for parents that their children no longer need to go to school with a school radius that is quite far away. Parents can monitor student activities at school.

a. Data normality test

Before further analysis, it is first necessary to know whether this research data has met the requirements for using statistics that will be used in hypothesis testing. Testing the analysis requirements for the use of correlation statistics is that the data obtained are at least normally distributed. Data normality test is done to find out whether the data of this study have met the requirements of using statistics that will be used in hypothesis testing.

The normality test is used the chi-square formula, with the criteria if the value of ChiSquare is smaller or equal to the price of Chi-Square table $\left(\mathrm{X}_{\mathrm{h}}^{2} \leq \mathrm{X}_{\mathrm{t}}^{2}\right)$, then the distribution is declared normal, and if greater $(>)$ declared abnormal

Table 3.

Research Data Normality Test Results

\begin{tabular}{|l|c|c|c|c|}
\hline \multicolumn{1}{|c|}{ Variabel } & df & $\mathrm{X}^{2}$ count & $\mathrm{X}^{2}$ table & Explanation \\
\hline Interest in reading & 9 & 14,80 & 16,92 & Normal \\
\hline Service quality & 9 & 8,80 & 16,92 & Normal \\
\hline
\end{tabular}

Source: Data Processing Results, 2019

The data in table 3 shows the calculated X2 value from the application of students' reading interest in the Library and the calculated X2 value of library service quality, the value is smaller than the X2 table, thus based on normality testing the data shows that the group is normally distributed. 


\section{b. Correlation product-moment test}

The result of the product-moment correlation calculation is 0.678 , the coefficient significance level is 0.00 , this number is far below the 0.05 probability, then the correlation between service quality and student interest in reading is significant or very real.

From the ANOVA test or F test, it was obtained that the count was 83.561, with a significance level of 0.00 much smaller than 0.05 , then the regression model could be used to predict service quality. T-test to test the significance of constants and independent variables namely reading interest from the coefficient table shows that the t-count value of the reading interest variable is 9,138 with a significance level of 0,00 , also under 0.05 so $\mathrm{H} 0$ is rejected and $\mathrm{H} 1$ is accepted or the quality of library services is correct have a significant effect on students' interest in reading in the library.

The level of correlation or correlation between the quality of library services to the reading interest of students in the library based on the calculation of the product-moment correlation of $r=0.678$ is at intervals of $0.60-0.799$ or strong. This means that the level of relationship or correlation between the quality of library services on the reading interest of students in Perpusakaan is at a strong level. The R square figure is 0.460 in the model summary table, meaning that 46.0 percent of damage service quality can be explained by the variable students' interest in reading while the remaining 54.0 percent is explained by other variables not examined in this study.

\section{Discussion}

\section{Quality of Services at the University of Timor Library's UPT}

The quality of libraries in Timorese universities that are still classified as not optimally must always be thoroughly improved based on at least 5 indicators of service quality, namely appearance, reliability, responsiveness, assurance, and empathy must always be promoted for the improvement of human resources in the border area. As a tertiary institution in the border area, the Timor University Library must be a representative and front-run library for the border community in general and students and academics in particular, whose existence is far from the city center.

Good service quality certainly pay attention to the comprehensive both internally and externally the service itself and always make corrections and evaluations of customer perceptions. As stated oleh (Zeithaml, 1988), defines that: "Service quality is an evaluation focus that reflects customer perceptions about service quality reliability, assurance, responsibility, empathy and physical."

In this case, the achievement of the quality of service at the University of Timor Library depends very much on the value of perception that can be reflected by customers, in this case, the students of the University of Timor which can be viewed from the elements of reliability, assurance, responsibility, empathy and physical besides the success of the service is also very dependent on alignment ability, attitude, appearance, attention, action, and responsibility in its implementation. 
150 Jurnal Administrare: Jurnal Pemikiran Ilmiah dan Pendidikan Administrasi Perkantoran

Volume 6 Number 2 July- December 2019. Pages 145-152

\section{Student Reading Interest in the Library}

The development of science in higher education by students in particular is very much determined by the interest in reading students in the library as a reliable source of reference. With students 'interest in reading at the University of Timor Library which is still aggressively a great concern for universities to stimulate things that can increase students' interest in reading. Both increase student awareness and willingness to visit the Library as well as institutional factors that motivate students to access resources information in the library such as books, articles and others.

Quoting (Corey, 1940) stated that interest in reading is influenced by two groups, namely personal factors and institutional groups. Personal factors are factors that originate within the child itself include: age, gender, intelligence, reading ability, attitude, psychological needs. Institutional factors are factors originating from outside the individual itself which include: (the availability of books, socioeconomic status, the influence of parents, peers and teachers. In addition, the quality of UPT Library services at the University of Timor which is still low is a separate factor. The lack of interest in reading students at the University of Timor Library.

\section{CONCLUSION}

Based on the results of the study, the quality of UPT library services at the University of Timor in terms of physical appearance, reliability, responsiveness, empathy is quite good in the category. The reading interest of UPT Library students at the University of Timor is in quite a good category. This is evidenced by the average value (mean) of 20.56 which is in the quite good category. The level of correlation or correlation between the quality of library services to the reading interest of students in the library based on the calculation of product-moment correlation of $r=0.678$ is at intervals of $0.60-0.799$ or is in the category of strong correlations. This means that the better the quality of service, the higher the interest in reading students in the Library.

\section{REFERENCES}

Anita Nusantari. (2009). Penerapan Manajemen Pengetahuan Untuk Meningkatkan Kinerja Perpustakaan Perguruan Tinggi. Visi Pustaka.

Ardoni. (2006). Teknologi Informasi: Kesiapan Pustakawan Memanfaatkannya. Studi Perpustakaan dan Informasi.

Corey, S. M. (1940). How to Increase Reading Ability. Journal of Educational Psychology. https://doi.org/10.1037/h0051623

Diniaty, D., \& Fairus, M. (2014). Analisis Faktor-Faktor Yang Mempengaruhi Kinerja Pegawai Perpustakaan Uin Suska Riau. Jurnal Sains, Teknologi dan Industri. https://doi.org/ISSN 1693-2390 print/ISSN 2407-0939 online ANALISIS

Fitriastuti, F. (2009). Aplikasi OPAC (Online Public Access Catalog) pada Sistem Informasi Perpustakaan Berbasis Mobile. Jurnal Dinamika Informatika.

Hayati, N. (2014). Komunikasi dalam Organisasi Perpustakaan. Ilmu Perpustakaan \& 
Kearsipan Khizanah Al - Hikmah.

Ismail, I., \& Darwis, M. (2016). Efektivitas Pelayanan Perpustakaan Sekolah Bagi Siswa di SMK Negeri 1 Pare-Pare. Jurnal Office, 2(2), 215-220.

Istiana, P. (2016). Kolaborasi Perpustakaan \& Stakeholder. JIPI (Jurnal Ilmu Perpustakaan dan Informasi). https://doi.org/http://dx.doi.org/10.30829/jipi.v1i2.560

Nurdin, A. A., Niswaty, R., \& Saleh, S. (2015). Minat Baca Mahasiswa Program Studi Pendidikan Administrasi Perkantoran Fakultas Ilmu Sosial Di UPT Perpustakaan Universitas Negeri Makassar. Jurnal Office, 1(1), 109-113.

Pratama, E. B., Sihombing, D. O., Nugraha, A., \& Putra, D. (2014). Aplikasi E-library Untuk Pengelolaan Data Buku Berbasis Web Pada SMA N 1 Sungai Raya Menggunakan Model Waterfall. Simposium Nasional Ilmu Pengetahuan dan Teknologi (SIMNASIPTEK).

Rangkuti, L. A. (2014). Pentingnya Pendidikan Pemakai (User Education) di Perpustakaan Perguruan Tinggi. Iqra.

Saleh, A. R., \& Komalasari, R. (2014). Pengertian Perpustakaan dan Dasar- Dasar Manajemen Perpustakaan. Manajemen Perpustakaan.

Suharti. (2017). Pengembangan Koleksi Untuk Memenuhi Kebutuhan Informasi Di Direktorat Perpustakaan Universitas Islam Indonesia. Buletin Perpustakaan.

Triatma, I. . (2016). Minat Baca Pada Siswa Kelas VI Sekolah Dasar Negeri Delegan. E-Jurnal Prodi Teknologi Pendidikan.

Widiasa, I. K. (2007). Manajemen Perpustakaan Sekolah. Jurnal Perpustakaan Sekolah.

Zeithaml, V. A. (1988). Consumer Perceptions of Price, Quality, and Value: A Means-End Model and Synthesis of Evidence. Journal of Marketing. https://doi.org/10.2307/1251446 
152 Jurnal Administrare: Jurnal Pemikiran Ilmiah dan Pendidikan Administrasi Perkantoran Volume 6 Number 2 July- December 2019. Pages 145-152 